\title{
To Each Their Own: Politics of Memory, Narratives about Victims of Communism and Perspectives on Bleiburg in Contemporary Serbia
}

\author{
JELENA ĐUREINOVIĆ \\ Justus Liebig University Giessen
}

\begin{abstract}
Summary
This article examines politics of memory on the Second World War and its aftermath in contemporary Serbia, focusing on the people executed or sentenced after the war and their framing. Discussing the dominant narratives and institutional and legal frameworks of official memory politics, the first part of the paper is concerned with the dynamics between different mnemonic agents, including non-state actors. Namely, commemorations and memorials dedicated to victims of communism come from below, from the groups considering the state efforts in this sphere insufficient. They are, however, supported by some political actors, the church, and Karađorđevic family. Finally, the paper looks at the perception of Bleiburg commemorations in media and political discourses in Serbia, placing it in the context of relations between the two countries concerning the memory of the war and its aftermath. As opposed to very similar tendencies in Croatia and Serbia, the political actors are concerned with their own victims respectively, framing them as the victims of communism. At the same time, the commemorations and rehabilitations happening in the other country are never acknowledged but condemned.
\end{abstract}

Keywords: Memory Politics, Revisionism, Chetniks, Bleiburg, Yugoslavia

In April 2014, an exhibition entitled "In the Name of the People! Political Repression in Serbia 1944-1953" was opened in the Historical Museum of Serbia in Belgrade, supported by the Ministry of Culture. Inspired by the House of Terror in Budapest, the exhibition was the first museum representation of the events taking place during the immediate aftermath of the Second World War in post-Yugoslav Serbia. The exhibition was announced as "the first multimedia exhibition about the topics that had been taboo for many years: executions, trials against people's 
enemies, Goli Otok and other camps, and forced collectivization". ${ }^{1}$ Prior to its opening, the exhibition was widely advertised and promoted in Serbian media, including the public broadcaster Radio Television of Serbia, representing the exhibition as revealing the hidden dark side of Serbian history. The author of the exhibition, the historian Srđan Cvetković, summarized the exhibition as having the goal to make "people in the 21 st century feel the atmosphere of the repression that was implemented first as the imitation of Stalinism and then as totalitarianism in Tito's style". ${ }^{2}$ The author's idea was to turn off electricity at the Nikola Pašić Square in front of the museum for the opening where the darkness would illustrate the atmosphere of the post-war terror.

The exhibition symbolizes the depiction of socialist Yugoslavia as the "long dark night" of national history which has represented the focal point of the official politics of memory in Serbia, particularly in the first decade after the overthrow of Slobodan Milošević. The politics of memory on the Yugoslav period are intertwined with the memory of the Second World War, as the war represented the site of birth and source of legitimacy for post-1945 Yugoslavia. Mnemonic hegemony centers on the interpretation of the end of the war and the immediate post-war period with the focus on the repression, executions, and trials, rather than liberation. This interpretation implies that the construction of the narrative of victims of communism, which is based on the very selective approach to historical events and records, where all persons who were victims of the "crimes of the liberators" are ascribed with the notion of innocence, regardless of their wartime role and activities. In this way, those considered collaborators or war criminals have become innocent victims of the communist regime and the People's Liberation War, and the liberation as its outcome has turned into revolutionary terror. The exhibition "In the Name of the People" follows this line. The exhibition poster represented the mosaic of the photographs of the victims of repression, including Milan Aćimović, the head of the Commissary Government, the first quisling government of occupied Serbia, and the Minister of Interior in the Government of the National Salvation led by Milan Nedić that followed. Furthermore, part of the exhibition was dedicated to Dragoljub Mihailović, the leader of the Yugoslav Army in the Homeland (more commonly referred to as the Chetnik movement), the royalist army officially representing the exile-government in London and on the side of the Allies until 1944, at the same time

$1<$ www.facebook.com/uimenaroda>, last accessed on 22 January 2017 . This is no longer the official Facebook page of the exhibition, but of the project and organization that have grown out of it.

2 "Srđan Cvetković: Osvetljavamo mračne godine Srbije", Večernje novosti, 13 October 2013, <www.novosti.rs/vesti/naslovna/drustvo/aktuelno.290.html:458560-Srdjan-Cvetkovic-Osvetljavamo-mracne-godine-Srbije>, last accessed on 22 January 2017. 
engaged in the armed conflict against the Partisans, collaboration with the occupation forces, and mass crimes against the civilian population. The issue of collaboration was not mentioned. Merging civilians as victims of post-war repression with the representatives of the collaborationist authorities and armed forces and framing them together in the narrative of innocent victims of communism is at the center of the historical reinterpretation of the Second World War and the post-war period in Serbia since the fall of Slobodan Milošević in 2000.

The main tendencies in the interpretation of contemporary history as summarized above can be related to contemporary politics of memory in Croatia, where Bleiburg represents the most prominent example of commemoration practices. As Kamberović explains, all existing models of revisionism of the recent and distant past in historiography, public discourses, and media can be noticed in the postYugoslav space, where the revision of the common Yugoslav past is what all postYugoslav countries have in common albeit with different intensities. The purpose of the revision of the Yugoslav period is to establish a clear discontinuity with it, in order to construct the pre-Yugoslav period in a more favorable way and find the historical arguments for strengthening the new nation-states and the ideologies in power. Kamberović emphasizes that Serbia and Croatia have gone furthest in that process (2007: 12). Similarly, Kuljić tracks the beginning of this process of "ideological historical revisionism" in former Yugoslavia back to much before the dissolution of Yugoslavia, in the revisionist controversies which were part of the Croatian Spring, the Linguistic Debate and the Memorandum of the Serbian Academy for Sciences and Arts. The only change which appeared after the dissolution of Yugoslavia is that revisionism started to manifest itself more openly in the public and became accepted by the newly-founded nation-states. The strong anti-communist and anti-totalitarian rhetoric, as a part of this revisionism, is used as a mask to hide the "dark periods of history" in an attempt to normalize and justify it (Kuljić, 2002: 21). In spite of the similarities in the official politics of memory and the interpretation of the Second World War and Yugoslavia in Serbia and Croatia, the common past in both countries has been interpreted in strictly national terms. Together with the dissolution of the common state, the Yugoslav regime of memory was broken along the national lines, "fragmented and disintegrated" (Höpken, 1999: 206). The nationalization of memory implies the focus on one's own victims within the otherwise similar mnemonic hegemonies that view the war and socialist Yugoslavia through the prism of post-war repression.

This article provides an overview of the politics of memory on the Second World War and the post-war period in contemporary Serbia with the particular focus on the memory of the Second World War actors who faced extrajudicial executions or trials in the post-war period. In the first part, the state-sanctioned politics 
of memory are discussed, examining their main characteristics as well as the institutional and legal frameworks. The second part is concerned with the wider dynamics of memory politics and collective memory in the Serbian society. The starting point for the analysis is the concept of collective memory as defined by Kansteiner, which is the interaction of three types of historical factors: the cultural and intellectual traditions that frame our representations of the past, the memory makers who selectively adopt and manipulate these traditions, and memory consumers who use, ignore, or transform such artifacts to their own interests (2002: 18). Moving beyond the state-oriented top-down approach, politics of memory are understood as "determined by the relations of forces between hegemonic master narratives, defiant counter-memories, and silent majorities whose historical experience is rarely articulated in public" (Molden, 2016: 125). Taking these ideas into consideration, politics of memory in Serbia are examined as dynamics between different mnemonic agents. The institutional and legal frameworks offered at the official level do not imply the visibility of the reinterpretation of the past in the public space. All commemorative practices and monuments marking the sites of memory come from below, from memory consumers who do not feel accommodated by the mechanisms of the state-sanctioned politics of memory since the year 2000.

Finally, the paper examines the perspectives on the Bleiburg commemoration in media and political discourses in Serbia with an outlook to the wider interactions between the two countries regarding the politics of memory on the Second World War and the post-war period. I argue that, although there are very similar dominant tendencies in both countries, the political actors in both Croatia and Serbia are concerned with their own victims respectively, framing them as the victims of communism and at the same time not acknowledging, but explicitly condemning the commemorations and rehabilitation of people from the other country.

\section{Memory Politics on the Second World War and the Post-war Period in Serbia}

The politics of memory on the Second World War and the post-war period in Serbia became strongly institutionalized after the fall of Slobodan Milošević in 2000. As Ramet explains (2011: 3), there were elements of historical revisionism about the Second World War during the Milošević era, but the serious debates about the Second World War among the groups with vested political interest in their outcome and the big push for the rehabilitation of collaborators came only after Milošević's fall. The key goal of the coalition of political parties that came to power in 2000 was to make a clear cut with the communist past, interpreting Milošević as representing the continuity of Yugoslav socialism which would make them the liberators of Serbia from communism (Stojanović, 2010: 17). In the strong anti-communist climate of the immediate post-Milošević period, the Second World War became the central 
object of revision, having represented the site of "the mythical birth of the communist regime" (ibid.: 13).

The year 2000 represents the large turn in politics of memory with the formerly existing but marginal narratives and interpretations of the Second World War making the transfer to the official sphere and becoming the focal point of the mnemonic hegemony. However, regarding politics of memory, the period since the overthrow of Milošević has not been homogeneous. The strongest strive for the delegitimization of everything associated with Yugoslavia and the Second World War narratives as the main source of its legitimacy was most evident throughout the first decade, during the dominant presence of the Democratic Party (Demokratska stranka, DS) in the state leadership. This is evident, for instance, in the parliamentary discussions on the legislation regarding veterans and judicial rehabilitation in 2004, 2006 and 2011, when the Democratic Party representatives proposed the legislation, and all voted in favor of it, the only party consistently opposing the laws being the Socialist Party of Serbia. The current government, with majority composed of the Serbian Progressive Party (Srpska napredna stranka, SNS), has not introduced any novel formal measures dedicated to the revision of the Second World War and state socialism. The issues such as judicial rehabilitation of Milan Nedić or Dragoljub Mihailović represent a consequence of the legislation adopted before 2012. Nevertheless, the attitude of the dominant political actors towards the past has not changed drastically.

I argue that there are three most important explanations of this dynamics in memory politics in Serbia. First, it can be argued that the revised interpretation of the Second World War and its actors had been established as the official narrative before the current government came to power, with the Chetnik movement formally and symbolically rehabilitated, hence not many further steps had to be taken in that direction. The participation of Oliver Antić, at the time the adviser of the President of Serbia Tomislav Nikolić, as a lawyer in the rehabilitation process of Dragoljub Mihailović at the very end and his insistence on behalf of the President to complete the process as soon as possible contributes to this explanation. It shows that the general attitude of the ruling parties towards the Second World War did not change, even with the above-mentioned shift to celebrating the victory in the war. Furthermore, the political parties currently dominant in power do not draw their legitimacy from the year 2000 and the overthrow of Slobodan Milošević, unlike the Democratic Party and other associated parties for whom the year 2000 represented the most important point of reference making them the carriers of democratic transition in Serbia. Finally, the current government represents the coalition of the Serbian Progressive Party with the Socialist Party of Serbia (Socijalistička partija Srbije, SPS) and the Movement of Socialists (Pokret socijalista, PS). The Socialist Party of Ser- 
bia is the second strongest party in Serbia, but they were also in the coalition with the Democratic Party from 2008 on, its representatives leading several ministries and the parliament. Their increasing prominence can be linked to the shift to the commemorations of the Partisans, discussed in the paragraph below. Although these parties are only nominally socialist and surely cannot be interpreted as leftist, they have constantly positioned themselves as the opponents to the initiatives regarding memory politics and rehabilitation during the previous period and promoted the narratives of preservation of the antifascist legacy of Serbia in the public. The paradox is that the Serbian Renewal Movement (Srpski pokret obnove, SPO) joined the coalition in 2014, the party that emphasizes both their opposition role during the 1990s and a very strong anti-communist and pro-Chetnik stance and that had also been in coalition with the Democratic Party before. ${ }^{3}$ Additionally, the close relations to the Russian Federation represent another factor contributing to the apparent revival of the commemorations of the liberation and victory in the Second World War happening most notably since 2012, to which Stojanović refers to as "the revision of the revision" (2011: 261).

Tracing the beginning of the process of revising the revision back to 2007, Stojanović points out to an important and gradual shift in the relation to the winners and the losers of the Second World War most obvious in the revival of the celebrations of the Day of the Liberation of Belgrade. The day was first deleted from the official calendar in 2000. However, starting modestly with Boris Tadić laying flowers on the Cemetery of Belgrade Liberators and becoming very prominent during the celebrations under the slogan "Belgrade remembers" that took place in 2009, the official celebrations of the Liberation Day culminated during the visit of Vladimir Putin in 2014. An hours-long military parade, “The Victors' March", was broadcast live on national television and actually held four days before 20 October so that the Russian president could attend. In the meantime, these commemorations, with a very strong military nature and with an emphasis on the Serbian army, have become a regular practice. Moreover, the flags and symbols of Yugoslavia and the Partisan units have been increasingly present at the celebrations of Liberation Day and other similar occasions involving the state and army support. They have, how-

3 This article was first submitted on 22 January 2017, but it should be noted that a fraction of the Serbian Renewal Movement that had been expelled from the party established their own political party, the Movement for the Renewal of the Kingdom of Serbia (Pokret obnove Kraljevine Srbije, POKS) in July 2017. This is a more radical wing of the SPO that promotes going back to the values and goals of the party from the early 1990s, that they believe to have been abandoned. Many members of the local government councils joined them, as well as a few members of the Vojvodina parliament, and they have one member in the Serbian National Assembly at the moment of revising the manuscript (May 2018). The party was officially established on the day of the execution of Dragoljub Mihailović. 
ever, been deprived of their political meaning and instead serve primarily performative and decorative purposes. Not only a simple shift to celebrating the Yugoslav memory culture based on antifascism, this process represents another aspect of the process of the post-Yugoslav nationalization of memory. Comparable to the focus on the Serbs as victims of communism, as discussed later in this article, these commemorations promote a national narrative that is not only depoliticizing the Yugoslav Partisans, but also "de-Yugoslavizing" and blending them into the narrative of Serbian antifascism and the Serbian victory in the Second World War. The fact that this happens in parallel to state-sponsored historical revisionism about the very same historical period illuminates the dynamic, inconsistent and contradictory nature of politics of memory. While understanding the relevance of this aspect of contemporary memory politics, this article, however, limits its scope to the discourses on victims of communism.

The main characteristics of state-supported historical revisionism in Serbia revolve around ignoring the Yugoslav historiography as ideologically manipulated, a demonization of socialism, a relativization and discreditation of the People's Liberation War and Yugoslav antifascism, the normalization of collaboration, and the victimization of collaborators who were executed by the Yugoslav Partisans or sentenced at post-war trials (Radanović, 2011: 260). In other words, the politics of memory, most notably in the period until 2012, is based on narratives of Serbian victimhood under the repression by the Yugoslav communist regime and centers on the political and legal rehabilitation of the Chetnik movement as a national resistance movement "who sought to avoid excessive Serbian losses" (Sindbæk, 2009: 52). The members of the Chetnik movement with their leader Dragoljub Mihailović have become a symbol of victimhood. They symbolize the wider tendency of the discursive construction of innocent victims of communism by looking at the whole Second World War and Yugoslavia through the lens of the post-war trials and executions while ignoring the wartime activities of the persons and movements concerned, such as collaboration, crimes against humanity, and persecution of different groups within occupied Serbia. The selective approach to and the interpretation of the war and the post-war period allows not only the rehabilitation of the Chetniks, but more prominent collaborators as well, such as the wartime Prime Minister Milan Nedić and other representatives of the collaborationist authorities in occupied Serbia.

Since the year 2000, Serbian official politics of memory has been promoted and most visible within institutional and legal frameworks. A small number of historians have played an important role in these frameworks, serving as expert witnesses in courts and as members of state-funded commissions. Additionally, the dominant interpretations of the Second World War and the post-war period have 
their roots in the works of these historians who represent the minority in the field by numbers, but are the most influential and play the role of mnemonic agents as well. The first important legal initiative were the changes of the Law on Veterans, War Invalids, and Members of their Families adopted in 2004. These officially equalized the members of the Yugoslav Army in the Homeland and the Ravna Gora movement with the People's Liberation Movement, granting the veterans of both armed movements the same status and rights. ${ }^{4}$ Moreover, two Rehabilitation Acts were adopted in 2006 and 2011, introducing the possibility of legal rehabilitation in court for those sentenced, executed, or deprived of any rights or property for political or ideological reasons. ${ }^{5}$ The vague formulation of the laws allows the rehabilitation of literally anyone regardless if there was a court or administrative decision prior to the execution, a sentence, or any confiscation of property and regardless of the wartime activities and responsibility, as long as it can be argued that there are ideological or political reasons involved. According to these laws, Dragoljub Mihailović was rehabilitated in May 2015, the court decision pronouncing his 1946 process and sentence incorrect and thus invalid. The rehabilitation of Milan Nedić started in December 2015 and is ongoing, as well as the rehabilitation of Nikola Kalabić, the commander of the Mountain Guard Corps (Korpus gorske garde), the most notorious Chetnik unit in Serbia, whose process started in 2013.

The Government of Serbia established two fact finding commissions in 2009, one in charge for locating the graves of the people executed in the territory of Serbia after 12 September 1944 and the other dedicated specifically to the investigation of the circumstances of the death of Dragoljub Mihailović. ${ }^{6}$ During the rehabilitation process of Mihailović, the two commissions joined forces in order to look for his remains. The search was accompanied by sensationalist media coverage with members of the commissions frequently appearing in the media to announce the expected discoveries. However, the commission did not discover any significant new

4 "Zakon o pravima boraca, ratnih invalida i članova njihovih porodica", Službeni glasnik Republike Srbije, 137/2004. It has to be noted that the significance of the law is that it equalized both movements nominally and symbolically, officially interpreting the Chetnik movement as antifascist and equal to the Partisans. However, its practical implementation regarding pensions was not fulfilled, because no Chetnik veteran has been approved the pension until now.

5 “Zakon o rehabilitaciji”, Službeni glasnik Republike Srbije, 33/06 and 92/2011.

${ }^{6}$ Officially: The State Commission for the Secret Graves of Those Executed after 12 September 1944 (Državna komisija za tajne grobnice ubijenih posle 12. septembra 1944) and the Government Commission for Investigating the Circumstances of the Death of Dragoljub Mihailović (Državna komisija za utvrđivanje okolnosti smrti Dragoljuba Mihailovića). Before they merged in the search for Mihailović's remains, the Mihailović commission which consisted predominantly of historians focused on archival research. 
information about the site of the execution or burial of Mihailović. The State Commission for the Secret Graves of Those Executed after 12 September 1944 (further: The Commission for the Secret Graves) had a mandate to "research, find, and mark all secret graves containing the remains of those executed after 12 September 1944" and to "locate and mark all grave sites and determine the exact number of those executed after September 1944". "The results of the Commission are available in an online database titled "The Open Book" which encompasses 59,554 names for the whole territory of the Republic of Serbia. ${ }^{8}$

The explicit goal of the Commission for the Secret Graves was to find and mark the grave sites and compose the list of those executed as opposed to those killed while fighting or disappeared, as it is stated in the name of the commission. Furthermore, the purpose of the Commission did not include any evaluation of the people killed after the liberation, but rather investigation in order to achieve factual knowledge about the numbers of people who lost their lives in Serbia. However, the database includes numerous cases of persons who lost their lives while fighting in armed forces, missing persons, as well as those, especially ethnic Germans from Vojvodina, who died in camps and were not killed directly. Moreover, some members of the Yugoslav Army in the Homeland who might have lost their lives while retreating and fighting against the Partisans in Bosnia are included in the list. Additionally, similarly to other mechanisms of memory politics related to this period, the work of the Commission and its representation in the media, also by the members themselves, attached the notion of innocence to people executed, indirectly representing them as the innocent victims of communism. The database allows for comments on each entry. However, there are no comments for persons who had been responsible for war crimes directly or by command responsibility. ${ }^{9}$ It has to be noted that it is a very difficult task to determine whether someone was innocent, or their persecution or execution can be justified. This was the response given by the Commission's secretary Srđan Cvetković when confronted with the issue of innocence, also stating that the task of the Commission was not to judge but just to list victims and grave sites. ${ }^{10}$ However, the media appearances and academic publications of Cvetković and other members of the Commission leave out this problem and rather create the impression that all the victims were innocent victims of communism, executed for ideological and political reasons.

$7<$ http://www.komisija1944.mpravde.gov.rs/lt/articles/o-nama/>, last accessed on 2 May 2018.

$8<$ http://www.otvorenaknjiga.komisija1944.mpravde.gov.rs/>, last accessed on 20 January 2017.

${ }^{9}$ For a detailed analysis of the contradictions and flaws in the Commission database as well as the problems with the total number of victims, see Radanović, 2015: 546-598.

${ }^{10}$ Interview with Srđan Cvetković, Belgrade, March 2016. 
The outcome of the work of the Commission for the Secret Graves had a very positive effect in the context of debates and number games about the post-war executions and the structure of the victims. The dominant narrative promoted by several historians and publicists in Serbia, present in media discourses as well, included exaggerated numbers up to 300,000 persons executed and the claims that the Serbian population, most notably in central parts of Serbia, was the largest victim of the post-war executions. This was the view promoted in publications by historians who worked in the Commission as well. Furthermore, the claims that the Chetnik movement was completely physically destroyed by the Partisans and Yugoslav authorities have been a common place in numerous publications. The Commission results proved these claims wrong. First, the current number of victims is lower than 60,000 , out of which $68,85 \%$ came from Vojvodina and were by majority German or Hungarian. The territory of Serbia without Vojvodina and Kosovo covers $27,59 \%$ or 25,219 persons. ${ }^{11}$ The Germans from Vojvodina cover the largest ethnic group and Serbs in whole Serbia make up $26,30 \%$ of all listed persons. The study conducted by Radanović revealed that more than seven thousand persons listed in the database in 2014 were members of the Yugoslav Army in the Homeland, which comprises $49,07 \%$ out of all victims in central Serbia. Taking into account that the Yugoslav Army in the Homeland had around 25,000 members in August 1944 according to the German documents, it is evident that the majority of the Chetnik movement from Serbia survived the war and the post-war period (Radanović, 2015: 595). Around one half of the Chetniks switched to the Partisan side in Summer 1944 when the Allies decided to give their support to the Partisans, while amnesty was offered to those who had not committed war crimes. Based on the Commission data, it can also be concluded that civilians did not represent a majority of those executed within Serbia, because members of the Yugoslav Army in the Homeland and other armed forces covered more than a half of the Serbian victims.

As opposed to the results of the Commission for the Secret Graves, its members, most notably Srđan Cvetković who is the main media representative of the Commission, still insist on similar arguments as before the Commission's list had been created. In his latest publication, Cvetković provided the analysis of the structure of the victims, arguing that most of the victims had been civilians and that the primary targets had been members of urban citizenry, critical intelligentsia, politicians, merchants, clerks, factory owners, priests, and wealthier peasants (2016). This argument is directly contradicting the results of the research he coordinated, but fits the wider tendency of the interpretation of the post-war executions and tri-

11 The numbers and percentage represented in this paragraph are based on the database as it was in 2014, when it encompassed 56,147 persons. 
als. This interpretation is focused on the destruction of the political, economic, and intellectual elites and wealthier peasants which have become central to the revisionist historiography and para-historiography in Serbia. The issue of collaboration and other wartime activities of those executed or sentenced is never openly mentioned in these discourses, but rather framed as "those accused of collaboration" or "designated as sympathizers, collaborators and people's enemies" (ibid.: 86-88). When interpreted in this way, the members of the Chetnik movement or the repressive apparatus of the Milan Nedić authorities become the victims persecuted as class enemies for solely ideological reasons. Additionally, ignoring the fact that most of the victims were members of armed forces and framing them as civilians supports the dominant narrative of the innocent victims of communism which again constitutes a central narrative of politics of memory in contemporary Serbia.

\section{Memory Consumers and Politics of Memory in the Public Space}

Although the state has invested many efforts in the field of memory politics directed at the separation from and delegitimization of socialist Yugoslavia and its main mnemonic narratives about the Second World War, which include addressing those considered as victims of communism through the possibility of rehabilitation and return of confiscated or nationalized property, no official commemorations or memorials dedicated to victims of communism have followed. The exception to this are street names but, although thousands of streets that used to commemorate the People's Liberation War have been renamed, there is no tendency of replacing the names with the names related to the Chetnik movement or other collaborationist forces of the Second World War. The commemorations explicitly dedicated to the Chetnik movement and other groups considered victims of communism as well as memorials in Serbia are not state-supported but are bottom-up initiatives by different groups of citizens or political parties. In other words, commemorative activities and memorial places usually come from below. The Association of Victims of Communism and Political Prisoners and the SPO represent the most prominent mnemonic agents in these initiatives. Furthermore, the commemorations and memorials are supported or attended by the representatives of the Serbian Orthodox Church and the Karađorđević family, most notably by Aleksandar Karađorđević, the son of King Petar II. Thus, the main actors in this sphere of politics of memory are not in positions of power, but they have the support of the carriers of significant symbolic power in the Serbian society.

The event, that by its significance for contemporary politics of memory would be comparable to Bleiburg, in Serbia would be the Battle of Zelengora in Bosnia in May 1945 which represents the final defeat of the Chetnik movement. The number of the Chetniks killed at Zelengora has been the object of debates, where his- 
torians sympathizing with the Chetniks of Dragoljub Mihailović claim that more than 9,000 Chetniks were killed there, although the available sources prove that no more than 3,000-3,500 Chetniks managed to get near Zelengora, with the difficulty to precisely determine how many of them were captured, killed while fighting, or escaped. The discrepancy in numbers is the result of the interpretation which identifies the total presence of the different Chetnik units in the wider Bosnian area as all killed in the battle or as prisoners of the Partisans afterwards. In spite of the importance that Zelengora has been ascribed to in some historiographical and other publications, the battle has nevertheless not become a relevant site of memory. ${ }^{12}$ Instead, the central commemoration in Serbia related to the Chetnik movement is the Ravna Gora Gathering (Ravnogorski sabor) that takes place in mid-May every year at the mountain of Ravna Gora, celebrating the anniversary of 13 May 1941 when Dragoljub Mihailović gathered the officers and formed the Yugoslav Army in the Homeland. It has been held there since May 1990 with the SPO erecting a monument to Dragoljub Mihailović and the memorial church at the site in the 1990s.

The commemoration at Ravna Gora revolves around the interpretation of 13 May 1941 as the beginning of the uprising of the Chetniks against the occupation, framing them as the first anti-occupation guerrilla in Europe. Although the commemoration takes place in the same week as the anniversary of the Battle of Zelengora, Zelengora does not represent a significant point of reference in the commemoration speeches. The Ravnogorski sabor focuses more on the celebration of the Chetnik movement and "the occasion of the anniversary of the organized guerrilla resistance of the Yugoslav Army and Ravna Gora movement against the Nazi occupiers of the Kingdom of Yugoslavia". ${ }^{13}$ The fallen Chetnik fighters are commemorated by a memorial service in a church with the event emphasizing the nature of the Yugoslav Army in the Homeland as a resistance movement, while their victimhood at the end of the war remains in the background. Besides the SPO and the Chetnik veteran association as the main organizers, the commemoration is supported by the Serbian Orthodox Church, Karađorđević family and the Kingdom of Serbia association.

The Republic of Serbia has not introduced any official holiday commemorating the victims of post-war executions and trials or the armed forces such as the

12 The commemorations and memorials to the Chetnik movement are more prominent in Republika Srpska than in Serbia, but the scope of this chapter is limited to the Republic of Serbia and the Chetniks of Dragoljub Mihailović without reference to different Chetnik revivals of the 1990 s in the form of paramilitary groups.

13 “Sabor na Ravnoj Gori 10. maja”, Blic, 7 May 2014, <http://www.blic.rs/vesti/politika/saborna-ravnoj-gori-10-maja/y5g1xpn>, last accessed on 21 January 2017. 
Chetnik movement. The gathering at Ravna Gora was officially supported and financed by the Ministry of Culture and the Government of Serbia only in 2005, when the Minister of Culture was from the SPO political party, but 13 May has not become an official holiday in Serbia. The changes in the official calendar of public holidays since 2000 were rather in removing the most important dates related to the People's Liberation War, such as the Day of the Uprising and the Day of the Liberation of Belgrade. However, similarly to the street names, they were not replaced by new holidays. The commemorations of the day of the execution of Dragoljub Mihailović in 1946 are held in July every year at several locations, usually in the form of a religious memorial service in churches, with the largest service held in the Saint Sava Temple in Belgrade. When Government representatives attend these events, it is usually by officials from the SPO party and rarely by individuals from other political parties. Furthermore, the Association of Victims of Communism and Political Prisoners, in cooperation with the Serbian Orthodox Church, organizes memorial services for victims of communism in general, which are also not supported by the state in any way.

Prior to the 2014 military parade celebrating the liberation of Belgrade, Oliver Antić, the advisor of Tomislav Nikolić and the plaintiffs' lawyer in the process of rehabilitation of Dragoljub Mihailović, advocated the idea of incorporating all victims of the antifascist struggle in the parade, regardless of their ideological affiliation. He was particularly in favor of the Chetnik symbols and flags alongside the Partisans' but justified the rejection of this idea as having to do with Mihailović not being rehabilitated yet, expecting that the Chetniks would be present at some future parades. ${ }^{14}$ This has not happened. Besides occasional support of the state officials to the Chetnik commemorations such as in 2005, the Chetnik movement has not been directly incorporated into the commemorative aspect of official politics of memory, including the most recent period and the shift towards the commemorations of the People's Liberation War. ${ }^{15}$ Nevertheless, both Boris Tadić and Aleksandar Vučić have indirectly supported the idea of two Serbian resistance movements in their commemoration speeches.

Similarly to the official holidays and commemorations, the politics of memory on the Second World War and the post-war period in Serbia do not include the con-

14 “Antić: Pravedno da obeležja četnika budu na paradi”, Danas, 2 October 2014, < https:// www.danas.rs/drustvo/antic-pravedno-da-obelezja-cetnika-budu-na-paradi/>, last accessed on 26 May 2018.

15 In May 2018, a photo of a group of uniformed men of the Serbian army laying flowers at the monument of Dragoljub Mihailović on Ravna Gora appeared on social networks. This caused a significant public attention, but the Ministry of Defence issued the official statement claiming it had not been an official army delegation. 
struction of monuments. Nevertheless, there are numerous memorials dedicated to the Chetnik movement and persons executed in the post-war period in Serbia. ${ }^{16}$ All of these memorials come from below and are initiated and financed by local people, family members or sympathizers of the Chetnik movement, usually with the support of the SPO or the Serbian Orthodox Church. For instance, the first monument to Dragoljub Mihailović was built in February 1992 at a private property in a village between Šabac and Valjevo, at Ravna Gora soon afterwards and also in several other towns in Serbia. The monuments commemorating the persons executed at the end of the Second World War, who were very often members of the Chetnik movement, are usually placed at cemeteries or church yards. An interesting case is the memorial church of Saint Petka in Šabac, which is officially dedicated to "the victims of communist terror" and was built in 2006 on the initiative of local groups of citizens and holds a memorial service for the citizens of Šabac executed in 1944 every year. Additionally, individuals or groups also create and put up commemorative plaques at the sites of executions or imprisonments.

The interviews conducted with members of the Association of Victims of Communism, SPO officials, and local actors from Šabac, reveal that these groups see the recognition in public space in form of a memorial as most relevant. The 2004 recognition of Chetnik veterans as equal to Partisans and the possibility of legal rehabilitation are perceived as a step towards coming to terms with the totalitarian past, but deemed as not sufficient. A memorial to victims of communism at a central location in Belgrade is perceived as the most important goal. Because of the lack of initiative by the state institutions regarding monuments, some of the groups, most notably the Association of Victims of Communism and the Chetnik veteran association, have submitted requests to the Commission for Monuments and Names of Streets and Squares of Belgrade. The Commission has not approved them until now. The Chetnik veteran association strives for a memorial to Dragoljub Mihailović at Ada Ciganlija in Belgrade as well, where he was probably executed.

${ }^{16}$ In Vojvodina, there are marked sites of memory where ethnic Germans and Hungarians were held in camps or were executed. Many of those, such as the execution site in Bački Jarak near Novi Sad, the memorial plaque in Apatin, the memorial to Germans in Gakovo near Sombor and at the cemetery in Sremska Mitrovica, are marked and commemorated by the associations of Vojvodina Germans, often supported by the local municipality but without the official governmental support of Vojvodina or Serbia. The exception is the memorial to Hungarian victims in Čurug, where both the President of the Republic of Serbia Tomislav Nikolić and the President of Hungary Janos Ader attended the unveiling ceremony in 2013. 


\section{Perspectives on Bleiburg in the Serbian Media and Political Discourses}

The process of "nationalizing memory" in both Serbia and Croatia started in the 1980s (Höpken, 1999: 206). During the 1990s, there was a strong urge to rescue Croatian or Serbian identity from the perceived threat of the Yugoslav one and communist crimes were utilized for nationalist mobilization purposes from the 1990s onward (Subotić, 2014: 191). The issue of communist crimes and dealing with them was largely hijacked by the nationalist elites and far right which is an important factor for the dynamics between Serbia and Croatia concerning the memory of the Second World War and Yugoslavia. Another important factor is the return of the political and media actors from the Milošević era and their dominance in the public sphere in Serbia.

Reflecting the state-supported memory politics, the dominant media discourses related to the end of the Second World War and the post-war period in contemporary Serbia are centered on the repression and the executions in Serbia itself or affecting Serbs. Bleiburg is generally considered either a Croatian commemoration or a proof of the Ustasha revival and historical revisionism in Croatia. It is mentioned in the Serbian press rarely, occupying headlines only on the occasion of the commemoration. Moreover, there are almost no public reactions or comments on the commemoration coming from politicians and state officials. As opposed to that, the processes of legal rehabilitation, such as Dragoljub Mihailović in Serbia in 2015 and of Alojzije Stepinac in Croatia in 2016, provoke public reactions in both countries.

In general, when reporting about the Bleiburg commemoration, Serbian mainstream daily newspapers normally publish news agency reports or public statements of non-governmental organizations and persons. This practice implies that there is no editorial or author's intervention in the text, and that reports and statements are published in their original form. If there is any opinion or criticism towards the commemorations, it is predominantly expressed within the original news agency report or statement, representing the supporting or critical voices from Croatia, usually all newspapers repeating the same content. On the other hand, some of the media, most notably one of the most read newspapers Večernje novosti, have adopted the practice of adding sensationalist headlines which reflect their view on the commemorations. ${ }^{17}$ These headlines are followed by the original news agency content.

17 Some of them include, but are not limited to: "Croats do not want to end the war against Serbs", "New Ustaša provocation", "Is the notorious year 1941 making a big comeback in Croatia?", "Ustaše go wild in Bleiburg", "Ustaša rampage in Srb". These headlines are all taken only from Večernje novosti as examples. While other mainstream daily newspapers have more neutral headlines for the news agency reports on Bleiburg, the printed and online tabloids use stronger and more extreme language, often using the term "Ustaša" when referring to Croatia and Croats in general. 
The fact that particularly Večernje novosti represents the newspaper with the clearly expressed negative view on Bleiburg reflects the wider tendency in which Serbian victims, regardless of their wartime activities, are framed as innocent victims of communism while those commemorated in Bleiburg or Slovenia are the Ustasha and always explicitly marked as quislings, fascists, and war criminals. ${ }^{18}$ Regarding the memory of the post-war period, Večernje novosti is a very clearly positioned newspaper that gives significant space to topics related to those understood as victims of communism, including the rehabilitation and restitution processes. Their style of reporting is based on personal stories and testimonies of those considered as victims and their families. Their stories are approached in a very warm and tragic way, representing the persons in question as innocent victims and strongly condemning the Yugoslav regime. Večernje novosti is an example of a wider tendency in print media, such as Blic and Glas javnosti, where the "human story" is used as a bait for readers (Lazić, 2011: 272). During the process of rehabilitation of Mihailović, Novosti regularly published stories about him from a very personal or family perspective with the reporters visiting his birthplace and the family house and publishing the letters from his daughter Gordana. Furthermore, five feuilletons about Mihailović were published from 2009 to 2015. The testimonies of his combatants and daughter as well as the feuilletons that included the phrases such as "the martyr" or "tragic person of Serbian history" in the headlines had a goal of bringing Mihailović closer to the readership and perpetuating the image of him as a victim.

Moreover, Večernje novosti is the newspaper that can be understood as a mnemonic agent besides its role as a medium. In 2009, the series of texts under the title "Unearthing the Truth" was published in cooperation with the Institute of Contemporary History, encompassing the month-long everyday publication of the lists of the secret graves and victims of the Yugoslav regime in Serbia, followed by testimonies and confessions of the victims and their descendants. This action was followed by a roundtable discussion with the same title organized by Večernje novosti, where the newspaper representatives, together with the above-mentioned institute, participated with the government officials. The outcome of the roundtable was the submitted request for the establishment of an investigative commission for secret graves, which was finally established in the same year. The reaction of the state and the establishment of the commission represented the main goals of the initiative, which was confirmed by the newspaper later: "We managed to upset the public and

${ }^{18}$ What is also important is that two media actors well known for their warmongering role in the 1990s have been editors in chief of Večernje novosti since 2013 - first Ratko Dmitrović and then Milorad Vučelić since 2017 (the director of Radio Television Serbia and vice-president of the Socialist Party of Serbia during the period of Milošević's rule and the wars of the Yugoslav dissolution). 
practically force the state to form the commission for investigating secret graves of victims of the communist terror. The goal of the action was to reveal the truth that would cause the historical reconciliation of Serbs and the rehabilitation of those executed." 19

When reporting about those executed by the Yugoslav Partisans or sentenced in the immediate post-war period, the focus of Večernje novosti is on their victimhood and suffering of their families during Yugoslavia. The issues such as collaboration are always left out, also when it comes to the more prominent individuals such as Dragoljub Mihailović or Milan Nedić. As opposed to that, when a member of the Ustaša movement is rehabilitated in Serbia, such as in the case of Petar Holjac who was executed after the liberation of Zemun in 1944 and whose property was also confiscated, their collaboration or participation in the occupation is not left out, but rather emphasized. In the case of Holjac's rehabilitation in 2016, the article was illustrated with the scanned archival document confirming his membership in the Ustaša movement and a photo of him on a military parade in Zemun, clearly emphasizing that he was a representative of the occupation regime. ${ }^{20} \mathrm{~A}$ critical approach towards rehabilitation by the authors of the articles themselves, such as in this case, is not typical for the media paradigm in Serbia in general. Besides the articles on people from Serbia, the Chetnik units from Montenegro who were handed over to the Yugoslav authorities by the Allied forces in 1945 in Austria and executed in Slovenia are a prominent topic with a focus on their suffering. Nevertheless, while framing everyone as an innocent victim of communism, the commemorations of the Ustaša are strongly condemned and framed as an example of the wider process of rehabilitation of fascism in Croatia. The crimes of the Ustaša movement are always in the focus and Večernje novosti constantly emphasizes that no one speaking at the commemoration mentions the crimes in their speech.

The information whether the Croatian Government and the Parliament support the Bleiburg commemoration institutionally or financially is framed to be very important and can be found in all reports or articles about Bleiburg in Serbia. Furthermore, Serbian media put an emphasis on the politicians and state officials who attend the commemoration. The fact that "even" Franjo Tuđman never visited Bleiburg as opposed to the political leadership afterwards is very strongly emphasized, especially since Kolinda Grabar-Kitarović became the President of Croatia

19 “Rehabilitacija, pa pomirenje", Večernje Novosti, 28 January 2011, <http://www.novosti.rs/ vesti/naslovna/aktuelno.69.html:315594-Rehabilitacija-pa-pomirenje>, last accessed on 6 January 2017.

20 “Sud rehabilitovao Ustašu!”, Večernje novosti, 26 March 2016, <http://www.novosti.rs/vesti/ naslovna/drustvo/aktuelno.290.html:597424-Sud-rehabilitovao-ustasu>, last accessed on 8 January 2017. 
in early 2015. Furthermore, the assumption was that there would be significant criticism in the Serbian public towards the political and institutional support for the Bleiburg commemoration in Croatia. However, it can be concluded that Serbian politicians and state officials generally avoid commenting on it. The exception to this tendency is Aleksandar Vulin, the Minister of Labor, Employment, Veteran and Social Policy in the Government of Serbia from 2014 and Minister of Defense since 2017, who has issued numerous statements related to the memorialization of the Second World War in Croatia. His statements, which are always published in all media in the original form and without a comment, condemn the Bleiburg commemoration and the state support for it, constantly warning about the "fascization as a part of the official policy of the Croatian state". ${ }^{21}$ After the 2016 commemoration, Vulin issued the statement calling for the European Union to react on the Croatian political leadership paying respect to the executed Ustaša, adding that Serbia "would not watch quietly while 'Ustashdom' (ustaštvo) was born, developing, and growing”. ${ }^{22}$

As opposed to that, court rehabilitations in both countries seem to provoke more significant negative reactions and debates. The rehabilitation of Dragoljub Mihailović sparked reactions from Croatia in 2012 which were then answered from Serbia and revolved around the narrative that politicians from Croatia had no right to criticize because the Ustaša had been completely rehabilitated there already in the $1990 \mathrm{~s}$, representing the main foundation of the Croatian state today. ${ }^{23} \mathrm{~A}$ similar tendency was present in the public when Alojzije Stepinac was rehabilitated in Zagreb in July 2016. The Serbian newspaper headlines deemed the rehabilitation of Stepinac as "shameful" and "scandalous", while several government officials and political parties issued statements condemning the rehabilitation outcome and ascribing it the larger significance as the rehabilitation of the Ustaša movement and the Independent State of Croatia as a whole. In this way, the Serbian Minister of Foreign Affairs Ivica Dačić interpreted the rehabilitation of Stepinac as the rehabilitation of the "fascist Ustaša Independent State of Croatia", similarly to Aleksandar Vulin who called it the rehabilitation of fascist politics which legitimized the

21 "Vulin: Fašizacija je deo zvanične politike Hrvatske", Blic, 4 August 2016, <http://www.blic. rs/vesti/politika/vulin-fasizacija-je-deo-zvanicne-politike-hrvatske/sg9r3tj $>$, last accessed on 9 January 2017.

22 "Vulin: EU da kazni Hrvatsku zbog Blajburga", Blic, 15 May 2016, <http:/www.blic.rs/ vesti/politika/vulin-eu-da-kazni-hrvatsku-zbog-blajburga/zgbcsbc>, last accessed on 9 January 2017.

${ }^{23}$ For an example of this debate in 2012, see "Rehabilitacija Draže: Hrvati spremni samo na mržnju”, Večernje novosti, 31 March 2012, <http://www.novosti.rs/vesti/naslovna/aktuelno.290. html:373403-Rehabilitacija-Draze-Hrvati-spremni-samo-za-mrznju>, last accessed on 8 January 2017. 
crimes committed in Jasenovac and the Ustaša movement and the state in general. ${ }^{24}$ Besides the tendency to interpret the rehabilitation of Stepinac as the rehabilitation of the Ustaša state and fascism, the court decision was also commented on in the correlation with Serbia, either interpreting Serbia as having preserved the legacy of antifascism unlike Croatia or, more rarely, linking the Stepinac rehabilitation to the ongoing rehabilitation processes in Serbia and criticizing both. ${ }^{25}$

Although Bleiburg does not represent a prominent topic in the Serbian media, there is nevertheless a media paradigm in reporting about its commemoration as well as other cases of the memorialization of anything related to the Independent State of Croatia. This paradigm has a few main characteristics. First, the practice of media reporting reflects the politics of memory in Serbia where the persons framed as the victims of communism in Serbia and those from Croatia who faced post-war executions and trials are perceived as two completely separate issues, regardless of the same regime that is in both cases perceived as a perpetrator. Second and in relation to the previous point, when reporting about Bleiburg, rehabilitations, and memory of the Second World War and socialist Yugoslavia in Croatia in general, Serbian media as well as public officials usually do not refer to Serbia in the same context, where very similar narratives about contemporary history are promoted and dominate the mnemonic space. This relates to the paradox of the perception of the common past of two countries as separated in the dominant media and political discourses. The same media or persons which are strongly condemning the commemorations, pension legislation, or rehabilitation in Croatia are at the same time discussing similar tendencies in Serbia in a neutral or positive way, very often framing it in the narrative of coming to terms with the authoritarian past. The rehabilitation is usually not reflected upon and brought into correlation, except in the case of the rehabilitation of Mihailović and the debates surrounding it in 2012, when the proponents of his rehabilitation emphasized the difference between the Ustaše and the Chetniks in order to justify the Chetnik rehabilitation. Third, many of the newspaper articles and public statements refer to Serbia as preserving the

24 “Stepincu oprost zločina”, Večernje novosti, 22 July 2016, <http://www.novosti.rs/vesti/planeta.300.html:616266-SRAMOTA-Rehabilitovan-Alojzije-Stepinac $>$, last accessed on 9 January 2017; "Vulin: Rehabilitacija fašističke politike", Politika, 23 July 2016, <http://www.politika.rs/scc/clanak/359724/Vulin-Rehabilitacija-fasisticke-politike>, last accessed on 9 January 2017.

25 See: "Vucic: Croatia's Stepinac Ruling Says More About Croatia than Serbs and Serbia", Beta, 24 July 2016, <http://beta.rs/vesti/vesti-politika/37611-vucic-croatias-stepinac-ruling-saysmore-about-croatia-than-serbs-and-serbia>, last accessed on 9 January 2017; "LSV: Poništavanje presude Stepincu zaslužuje najoštriju osudu kao i rehabilitacija Draže Mihailovića”, NSPM, 22 July 2016, <http://www.nspm.rs/hronika/lsv-ponistavanje-presude-stepincu-zasluzuje-najostriju-osudu-kao-i-rehabilitacija-draze-mihailovica.html>, last accessed on 9 January 2017. 
Yugoslav legacy, while Croatia is seen as striving for erasing its Yugoslav past and rehabilitation of fascism. ${ }^{26}$ Finally, Bleiburg is very often confronted with the nexus of the Jasenovac concentration camp and the Serbian victimhood under the Ustaša regime, in which case the commemoration in Bleiburg is interpreted and criticized as the relativization of Ustaša crimes and the equation of the victims of Jasenovac and Bleiburg as an equation of victims and perpetrators.

\section{Concluding Remarks}

The state-funded politics of memory on the Second World War and the post-war period in Serbia since 2000 have revolved around the separation from the Yugoslav memory culture and its main narratives, where the Second World War and more importantly the People's Liberation War represented the main legitimacy foundation for socialist Yugoslavia. The Partisan narrative was first replaced by the narratives of victimhood under the communist regime that went hand in hand with the positive reinterpretation of the Yugoslav Army in the Homeland. The Chetnik movement and their rehabilitation became the central point of politics of memory, framed parallelly as both the symbol of the Serbian victimhood in the post-war period in Yugoslavia and as the national resistance movement not led by the Communist Party. The institutional and legal frameworks of the politics of memory in Serbia center on the recognition and accommodation of those considered as victims of communism. However, this tendency implies the idea of innocence attached to all persons persecuted in the post-war period regardless of other grounds for their persecution other than political and ideological reasons. The problem of collaboration and war crimes among the members of different armed forces and representatives of the quisling government of occupied Serbia are left out, selectively interpreting the war and the post-war period and equating all persons as innocent victims of communism. In parallel to this process, there has been a gradual shift to the commemorations of the People's Liberation War and the victory against fascism in particular, however, interpreted in strictly national terms and taken out of its ideological context.

${ }^{26}$ In a very thorough overview of the street names and monuments commemorating the Yugoslav period in the post-Yugoslav space, originally published in Večernje novosti in January 2016, but afterwards further distributed in other printed and online media, Serbia is used as an example of the state that preserved most of the street names from Yugoslavia. The critique centres on the argument that most of the street names referring to Serbia have been renamed in Croatia, while there are still hundreds of streets in Belgrade carrying the names referring to the People's Liberation War but also to persons from Croatia and other former Yugoslav republics. The two big waves of street renaming in Serbia (especially in Belgrade) in 1997 and in the immediate post-2000 period are not mentioned. See: "Tito u eks-ju opstaje, a sve srpsko brišu”, Večernje novosti, 17 January 2016, <http://www.novosti.rs/vesti/naslovna/drustvo/aktuelno.290.html\%3A586449-Tito-u-eksju-opstaje-a-sve--srpsko-brisu>, last accessed on 11 January 2017. 
The official politics of memory regarding victims of communism remains invisible in the state-sponsored commemorative and monumental landscape and the official calendar. The commemorations of the victims of communism as well as memorials dedicated to them are all the results of the initiatives of different groups, sometimes in cooperation with local authorities. They could be understood as coming from below, although they have support of the Serbian Orthodox Church and Karađorđević family which gives the acts of commemoration more symbolical power. Because of the lack of state support, the groups with personal or political interest in commemorating victims of communism do not feel recognized and addressed sufficiently.

The analysis of the public discourses about the Bleiburg commemoration in Serbia supports the argument that the national fragmentation of memory in the postYugoslav space resulted in competitive and separate national memory cultures in Serbia and Croatia. In each state, the focus of the official politics of memory and mnemonic practices is focused on the persons perceived as victims who belong to each nation respectively, while the same tendency in the other country is strongly condemned as rehabilitation of war criminals or fascists. Although the mnemonic hegemony in both Serbia and Croatia shares the similar negative interpretation of the common Yugoslav past with the focus on the Partisans and Yugoslav authorities as criminal, the memory cultures remain mutually exclusive.

\section{REFERENCES}

Cvetković, Srđan. 2016. The "Savage Purges" in Serbia in 1944/45, with a Brief Consideration of Yugoslavia as a Whole. Review of Croatian History, (12), 1: 67-102.

Höpken, Wolfgang. 1999. War, Memory, and Education in a Fragmented Society: The Case of Yugoslavia. East European Politics and Societies, (13), 1: 190-227.

Kamberović, Husnija. 2007. Između kritičke istoriografije i ideološkog revizionizma, in: Vera Katz (ed.): Revizija prošlosti na prostorima bivše Jugoslavije. Institut za istoriju. Sarajevo: 11-21.

Kansteiner, Wulf. 2002. Finding Meaning in Memory: A Methodological Critique of Collective Memory Studies. History and Theory, (41), 2: 179-197.

Kuljić, Todor. 2002. Historiographic Revisionism in Post-socialist Regimes, in: The Balkans Rachomon. Historiography and Literature on Dissolution of SFRY. Helsinki Committee for Human Rights in Serbia. Belgrade: 7-47.

Lazić, Sladjana. 2011. The Re-evaluation of Milan Nedić and Dragoljub Mihailović in Serbia, in: Sabrina P. Ramet and Ola Listhaug (eds.): Serbia and the Serbs in World War Two. Palgrave Macmillan. Basingstoke: 265-282. 
Molden, Berthold. 2016. Resistant Pasts Versus Mnemonic Hegemony: On the Power Relations of Collective Memory. Memory Studies, (9), 2: 125-142.

Radanović, Milan. 2011. Istorijska politika u Srbiji nakon 2000. Primeri manifestovanja sprege između akademskog istorijskog revizionizma i državne revizije prošlosti, in: Ana Veselinović et al. (eds.): Izgubljeno u tranziciji. Kritička analiza procesa društvene transformacije. Rosa Luxemburg Stiftung. Belgrade: 258-304.

Radanović, Milan. 2015. Kazna i zločin. Snage kolaboracije u Srbiji. Rosa Luxemburg Stiftung. Belgrade.

Ramet, Sabrina P. 2011. Introduction, in: Sabrina P. Ramet and Ola Listhaug (eds.): Serbia and the Serbs in World War Two. Palgrave Macmillan. Basingstoke: 1-14.

Sindbæk, Tea. 2009. The Fall and Rise of a National Hero: Interpretations of Draža Mihailović and the Chetniks in Yugoslavia and Serbia since 1945. Journal of Contemporary European Studies, (17), 1: 47-59.

Stojanović, Dubravka. 2010. U ogledalu drugih, in: Vojin Dimitrijević (ed.): Novosti iz prošlosti: Znanje, neznanje, upotreba i zloupotreba istorije. Belgrade Center for Human Rights, Belgrade: 13-33.

Stojanović, Dubravka. 2011. Revisions of the Second World War History in Serbia, in: Sabrina P. Ramet and Ola Listhaug (eds.): Serbia and the Serbs in World War Two. Palgrave Macmillan. Basingstoke: 247-264.

Subotić, Jelena. 2014. The Mythologizing of Communist Violence, in: Lavinia Stan and Nadia Nedelsky (eds.): Post-Communist Transitional Justice: Lessons from 25 Years of Experience. Cambridge University Press. New York: 188-210.

Jelena Đureinović is PhD Candidate and Lecturer at Justus Liebig University Giessen.

Mailing Address: Jelena Đureinović, Osteuropäische Geschichte, Philosophikum I 10 D, Otto-Behaghel-Strasse 10 D, 35394 Gießen, Germany.

E-mail: Jelena.Dureinovic@geschichte.uni-giessen.de 